\title{
PLE \& PLN FOR LANGUAGE LEARNING AND TEACHING: A CASE STUDY
}

\author{
Indire, Roma (Italy) / IIS Giordani-Striano, Naples (Italy)
}

\section{RESUMEN}

Los recientes desarrollos de las tecnologías de aprendizaje están facilitando un cambio significativo en la experiencia formativa. El objetivo de este trabajo es explorar el potencial de los PLE (Personal Learning Environments) y de los PLN (Personal Learning Networks) a través de la descripción de un caso de estudio sobre una iniciativa de formación online: una respuesta innovadora a la gestión integrada de la "formación permanente" para la enseñanza de idiomas. El caso de estudio se refiere a una iniciativa online desarrollada a nivel internacional en 2012 y dirigida a profesores, formadores y educadores de todo el mundo, apasionados del aprendizaje de idiomas, utilizando tecnologías. Los autores planearon y moderaron una prueba de cinco semanas durante el "EVO 2012" (Electronic Village Online), ofreciendo una oportunidad libre para discutir y compartir ideas, prácticas y experiencias gracias a encuentros sincronizados en la plataforma Moodle, a través de videoconferencias con expertos internacionales y herramientas de trabajo asíncronos. El objetivo principal fue promover la conciencia de este tema, acompañando a profesorado y formadores en la explotación de las potencialidades de los PLE y de los PLN en clases de inglés para fines específicos (EFL en sus siglas en inglés).

Palabras clave: PLE, PLN, Formación de profesorado, Aprendizaje de idiomas.

\section{ABSTRACT}

Recent developments in learning technologies are creating a significant shift in the educational experience. The paper aims at exploring the potential of PLEs (Personal Learning Environments) and PLNs (Personal Learning Networks) through the description of a case study relating to an online training initiative: an innovative answer to the "lifelong competency" management approach to language teaching. The case study refers to an online international initiative promoted in 2012 addressed to teachers, trainers and educators from all over the world, passionate about language learning with the use of technologies. The authors of this contribution planned and moderated a five-week training session within "EVO 2012" (Electronic Village Online), offering a free opportunity to discuss and share ideas, practices, experience through a Moodle platform, in synchronous meetings with international experts and asynchronous working tools. The main aim was to promote greater awareness of this topic, guiding teachers and trainers to the effective exploitation of the potential of PLE and PLN in EFL (English as a Foreign Language) classes.

Key words: PLE, PLN, Teacher Training, Language Learning

\section{PLEs \& PLNs in language learning}

In the last ten years, the twin concepts of Personal Learning Environment (PLE) and Personal Learning Network (PLN) have been offered as alternatives to more traditional environments and institutionally based courses, providing the opportunity to integrate the different dimensions of the learning process.

\footnotetext{
1Emails: I.cinganotto@indire.it ; danielacuccurullo@gmail.com
} 
Formal, non-formal and informal learning have become keywords of education in the 21 st centuries. In 1996, the OECD education ministers agreed to develop strategies for "lifelong learning for all" (OECD, 1996). The approach has been endorsed by ministers of labour, ministers of social affairs and the OECD Council at ministerial level. The concept of "from cradle to grave" learning refers to an approach whose importance may now be clearer than ever and non-formal and informal learning outcomes are viewed as having significant value. Policy-makers in many OECD countries are therefore trying to develop strategies to use all the skills, knowledge and competences individuals may have. Formal learning is always organized and structured, and has learning objectives; non-formal learning takes place through education organized for specific learners with specific learning objectives, outside the formal established system; informal learning is never organized, has no set objective in terms of learning outcomes and is never intentional from the learner's standpoint. Often it is referred to as learning by experience or just as experience within the individual's environment. The recognition of non-formal and informal learning is an important means for making the "lifelong learning for all" agenda a reality for all and, subsequently, for reshaping learning to match better the needs of the 21 st century knowledge economies and open societies.

Another key issue in 21st century education is the massive use of technologies, which have become an integral and essential part of our students' daily formal and informal interactions and communications (Farr \& Murray, 2016). To meet the challenges of the 21st century school, educators should rethink their style, considering technology as the heart of all the teaching practices (Stanley, 2013). Technology enhanced language learning (TELL) is turning out to be a very effective approach, as it enhances the students' motivation, with consequent better learning outcomes (Drexler, 2010; Terrel, 2011; Walker, White, 2013). The recently published European Commission report (European Commission, 2014), entitled Improving the effectiveness of language learning: CLIL and computer assisted language learning, fosters the use of technologies and mobile devices to implement language learning and the learning of content in a foreign language, mentioning the following examples:

- $\quad$ Authentic foreign language materials;

- Online environments, social media, or voice/video conferencing;

- $\quad$ Language-learning tools (apps or software);

- Online virtual learning environments;

- Game-based learning.

The report highlights the importance of social media and multimedia tools for language learning and CLIL (Content and Language Integrated Learning), as they can help build up an innovative and personalized learning environment and network with a community of practice of teachers, trainers, educators sharing the same interests and learning needs.

PLE and PLN can be placed within this framework and in line with the European recommendations, as for language teaching and learning is concerned.

The concept of PLE came out from discussions about Virtual Learning Environments (VLEs) and spread widely after the publication of a diagram depicting a future vision of VLEs by Scott Wilson. ${ }^{2}$ The first recorded mention of PLE as a concept was by Olivier and Liber (2001). Personal Learning Environments (PLEs) refer to the aggregation of single-functionality tools, which enable learners to have greater control over their own learning experience. This includes providing support for learners to set their own learning goals; manage their learning process; interact with peers during the learning process. Important concepts in PLEs include the integration of both formal and informal learning episodes into a single experience, the use of social networks that can cross institutional boundaries, and the use of networking protocols to connect a range of resources and systems within a personally-managed space. PLEs provide contextually appropriate toolsets by enabling individuals to select options based on their needs, so that learning demands, not technology, may drive the learning process. PLEs provide multiple

2http://www.flickr.com/photos/elifishtacos/90944650/ 
narratives and perspectives as a core function of the tool, reflecting the networked nature of society and knowledge today. A collection of different PLE diagrams is available on the edtechpost wiki ${ }^{3}$.

Unlike traditional top-down teaching models, which usually favour the "one expert" voice through the layout of learning materials and resources, PLEs do not generally pre-weight any particular node of knowledge, material or activity. The voice of the teacher/instructor is still important, but not essential, as the process of learning may involve a lot of other different voices. However, some authors have pointed out the importance of teacher competences in planning and design, instruction and learning, communication and interaction and use of technology (Shaikh, Khoja, 2012). There are different research strands on PLEs, some of which are more technologically-oriented (Chatti et al., 2010; Milligan et al. 2006; Wild et al. 2008), while others can be defined as more pedagogically-oriented (Attwell, 2007; Downes, 2010; Drexler, 2010). PLEs enable individual learners to build their own learning network (PLNs), filtering information deluge, connecting with others based on shared interest and seeking personal knowledge interests.

As Buchem et al. (2011) point out, the ideas of Personal Learning Networks (PLN) and Personal Knowledge Networks (PKN) are strongly associated with PLEs, reflecting the personal online networks for learning, activating at the same time, both tacit and explicit knowledge (Couros, 2010; Chatti et al. 2010). PLEs can include basic tools (such as blogs) to more complex structures. A simple blog or podcast may work well for instructors new to technology, while more skillful instructors may end up using a wider range of tools (collaborative webtools, social networks, etc.), to achieve specific learning aims.

In language learning/teaching, the use of PLE and PLN can be particularly effective, as it can meet the students' learning needs and styles, getting closer to their communication codes and channels, interweaving formal, non-formal and informal pathways. As depicted in the diagram below, the role of the teacher/instructor in the Personal Learning Environment refers to a series of competences, which can be grouped into 5 categories, according to Shaikh and Khoja (2012).

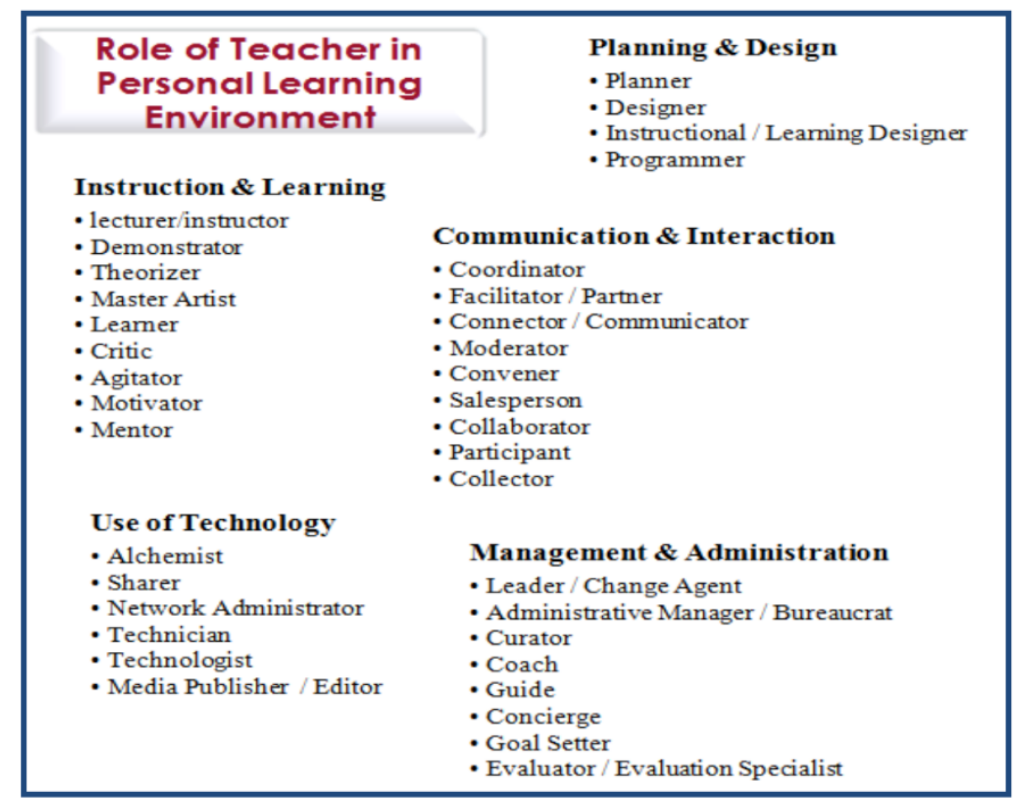

Fig. 1. The role of a teacher in Personal Learning Environment4

\footnotetext{
${ }^{3 h t t p: / / e d t e c h p o s t . w i k i s p a c e s . c o m / P L E+D i a g r a m s ~}$

${ }^{4}$ Adapted from Shaikh Z.A. \& Khoja S.A., (2012), p. 27.
} 
In general, "the concept of PLE marks a fundamental change in the role resources (people and media) play in teaching and learning"5. So PLEs and PLNs are an effective way to make students reflect on their own learning path, also considering the added value of social interactions and communications, as teaching and learning become a dynamic process involving not knowledge transmission or delivery, but co-construction, collaborative orchestration, remixing and integration of content and information. Haste (2009) identifies the co-construction of knowledge through interpersonal exchanges and interactions between a focus on knowledge-based instruction (Scardamalia \& Bereiter, 2006) and on praxis-based instruction (Atkinson, 2011).

While most pedagogy, of course, recognizes the interaction of both in good practice, there is nevertheless an underlying epistemological gap; knowledge-based models are implicitly more 'top down' and praxis-based more 'bottom up'. 'Knowledge' implies that the route to understanding is in the structured transmission of information. 'Praxis' implies a necessary interaction with materials, actions or other persons as a route to understanding" (Haste, 2009 p. 213).

The wide use of web tools and technologies in a PLE and PLN can enhance the learning process, the development of skills, abilities and competences relevant to any field, including foreign languages.

\section{The case study}

The following case study means to offer an example of an innovative training pathway on PLE and PLN and refers to an online international initiative promoted in 2012, which was addressed to teachers, trainers and educators all over the world, passionate about language learning with technologies.

\subsection{Target and aims}

The authors of this contribution planned and moderated a free online five-week training session within the international community of practice called "EVO" 2012 (Electronic Village Online ${ }^{6}$ ), which is made up of teachers, educators and trainers from all over the world, engaged in sharing ideas, practices, materials about language learning, CLIL (Content and Language Integrated Learning), technology enhanced language learning. The participants were a group of teachers and trainers from different countries, the majority of them from Italy; they made up a real community of peers and were all eager to learn more about PLE and PLN and start this new learning journey together.

The participants were mainly professors, experts in education, as well as adult educators, trainers, curriculum developers, consultants for multimedia teaching and foreign languages, interpreters and translators, "webheads" (as they like to call themselves), with previous experience of online education (as course coordinators) and a good knowledge and experience of e-learning platforms, resources and tools available on the net, without any previous experience/knowledge of PLE and PNE. The picture below provides visual information about the participants and their provenience.

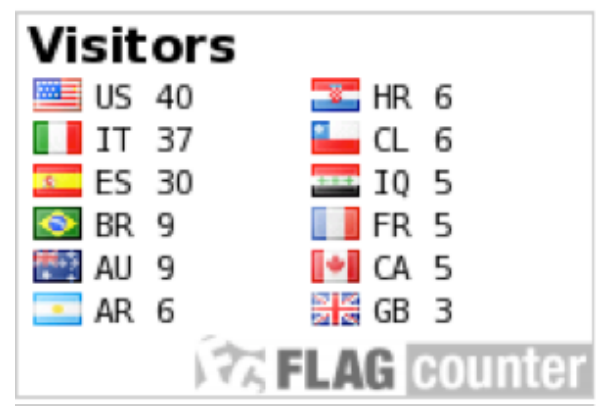

Fig. 2. The participants

57 things you should Know about Personal Learning Environments, Educause 2009, Creative Commons, http://www.educause.edu/eli.

${ }^{6}$ http://evosessions.pbworks.com/w/page/10708587/What\%20is\%20EVO 
The session took a look at the current situation by clarifying the concepts of Personal Learning Environments and Networks. Participants were guided to create their own PLE or PLN and select the Web 2.0 tools they wanted to use, as the five-week session evolved. The majority of the asynchronous/ asynchronous activities were carried out on a Moodle platform, but a lot of other working tools were used across the five weeks. Moreover synch meetings with international experts were organized in order to offer live interaction among the participants and with the experts. The basic idea was creating a framework for the development of each participant's own personal learning environment, through the synergy of formal and informal learning in a dynamic construction and with the recognition that the majority of learning occurs outside traditional learning formats. However, the main aim was to promote greater awareness of this topic, guiding teachers and trainers to the effective exploitation of the potential of PLE and PLN in EFL classes.

The session aimed at the following objectives:

- Becoming acquainted with a variety of digital venues by interacting with the group;

- Sharing information and knowledge in a community of learners/participants;

- Enhancing their digital literacy skills by reflecting on new ways of applying them;

- Analyzing examples of self-created and professional PLEs and PLNs;

- Participating in scheduled chats discussing content and pre-defined topics with the group;

- Having hands-on experience on how to create PLEs and PLNs;

- Innovating teaching/learning processes;

- Enhancing students' motivation;

- Integrating formal and informal learning to meet the "digital style" of the students and promote the key competences.

The main idea was a "multi-tool environment" for the production of digital content and the processing of knowledge outside the formal and institutional directions designed by the school curricula. Participants were offered the opportunity to explore and experiment the following tools:

- A wiki to collect the processes and activities of the community;

- Video-makers for digital storytelling.

- Geolocalization tools (for example: Community walk), to single out the different cities and locations the participants were from;

- A digital repository conceived as a diary of all the digital experiences of the participants (past, present, ongoing);

- Social bookmarkings for images, audio and video files;

- Map generators (for example: bubbl.us) to make the learning process systemic and organic;

- $\quad$ Tagcloud generators (for example: wordle.net) to show the key concepts and words in a lesson;

- An online environment for oral discussions in L2 (Voxopop), to share ideas, feelings and emotions avoiding the embarrassment of live interaction;

- A video sharing provider (Youtube) to share videos in L2 made by the attendees individually or cooperatively;

- A social network (Facebook) to keep in touch in an informal setting; 
Letizia Cinganotto \& Daniela Cuccurullo

- Digital poster generators (for example: Glogster) for the production of digital colorful posters on some particular issues in L2;

- Some other specific tools for the teaching/learning of $L 2$.

\subsection{The outline of the training pathway}

The training pathway developed across five weeks between January and February 2012, as briefly described below:

Week 1

The aims of the week were to introduce themselves to the group and get acquainted with the Wiki and the Moodle; familiarize with the terminology and the concept of PLEs and PLNs; take a survey of their personal tech capabilities, experience and needs.

Participants added interesting contributions to the discussion, as in the following examples:

Let's suppose that I get on a boat, any boat. I ride for a while and then get off. Further suppose that when I get off I am in a new place, a new community, a new environment. The boat will not be back for a while; it may never come back! If I want to get along I will have to learn how to get along. There are others here so the environment is hardly personal; yet, I will organize the environment in a personal way. I will establish a home base; different than most. Devise the locations and alternate locations of things necessary and develop methods to secure them. I will watch and copy others, ask and copy others and try and fail, try and fail honing methods of my own. Once all things necessary have been worked out, I will pretty things up a bit. Add some flare and style to my daily romp through the now not so new environment. I will have changed the environment, perhaps only slightly, based on my personal influence on it. The others I have contact with I would call a PLN. The subjective but real organizational template I impose on the environment I would call a PLE. Does this work for anyone?

It is interesting to understand the visual associations and images suggested by this training pathway.

This participant, for example, associates the concept of PLE and PLN to a boat trip: the aim is to survive and to learn how to get along, organizing the environment in a personal way at first. Later on it will be necessary to interact with other peers, maybe copying and learning from them. The personal and social dimensions are perfectly joined together in this definition, showing the deep understanding of the concepts that represent the topics of this EVO session.

PLE - It's my house. I can define things, such as if I'Il do the cleaning or not, when I'Il do it and if I'm going to ask for help or not. PLN - It's the club. I make some decisions, but I have people I can count on and some rules that I have to follow. Also, there are people who, somehow, need me and, for that reason, I have to think about them when I make some decisions, say things, etc.

In this comment the main idea is the house, with certain actions to do, decisions to take, rules to follow. Once again, from a different perspective, the personal and social dimensions are both relevant.

PLE and PLN are both learning environments; the difference lies in the scope, individual or social. This in turn is determined by each individual based on needs, wants, preferences, styles, interests, values, professional links, hobbies, access, personality, teaching style, etc.

The good thing about these new learning environments is they are eliciting changes in the ways of delivering learning for both teachers and students.

This is a more formal definition, sticking to the educational sphere. The key word here is "changes": the participant's perception is strongly affected by the idea of innovation in the learning processes both on the teacher's and the student's side.

I would favour a definition of PLE as a "physical" space where I can bring together my own "products" (such as blogs, eportfolio, etc) and different resources that I use in my learning process, like the student in 
the "Welcome to My PLE! vide0 ${ }^{7 "}$. Many of those resources would probably have been recommended by the members of my network (PLN). In short, I see a PLE more in the fashion of a Pageflakes (or similar) than as a list of links to tools that can be used to create content.

This last comment focuses on the learning experience with no visual associations: the teacher was impressed by a video showing examples of PLE and PLN and this struck his/her memory. So the idea is to collect evidences from his/her learning experiences through a sort of digital and social portfolio.

Only some of the participants' comments were reported here: creativity, phantasy and brightness of all these posts made it hard for us to select the ones to be mentioned in this paper.

\section{Week 2}

During this week, participants were guided through the exploration of web tools and their practical use and for educational purposes; the participants were also guided to analyze and evaluate sample PLE Frameworks in order to select a format for their own PLE/PLN project. Participants were introduced to various platforms to cultivate their PLE/PLN. Then they were invited to post their ideas on the Moodle about which tech tools they might use to develop their own. We also encouraged them to comment on at least two other peers' posts in order to promote a peer-tutoring activity. Different frameworks were analyzed as Personal Learning Environment (Elgg ${ }^{8}$, PeeblePad ${ }^{9}$, TamTamy $^{10}$, NING; etc.) in order to identify an ideal model applicable in different contexts. Among others, participants found the models of APLaNet ${ }^{11}$ and of the Personal Learning Network for Educators on a NING website ${ }^{12}$ interesting (see picture below). The concept of Webtop, a PLE, a conceptual evolution of the system integrator was also broadened.

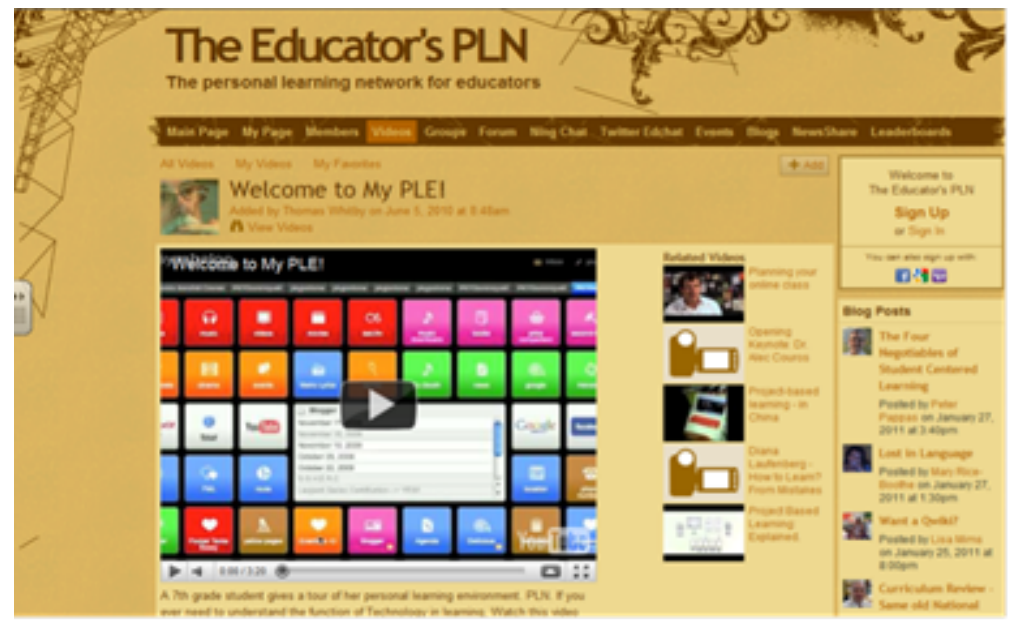

Fig. 3. The Educator's PLN

Participants were introduced to tools used or mentioned in the session and examined their practical use and implementation. They were guided to analyze, discuss and evaluate PLE Frameworks; they also selected a format for their own PLE/PLN project and added their personal definition of PLEs and PNEs in the glossary.

\footnotetext{
${ }^{7} \mathrm{https://www.youtube.com/watch?v=YEls3tq5wlY}$

${ }^{8}$ Elgg.org

9http://www.pebblepad.co.uk/

10http://www.reply.eu/tamtamy-reply/it/

11 http://www.aplanet-project.eu

https://www.facebook.com/aplanetproject/?fref=ts

12http://edupln.ning.com/
} 
Week 3

During this week, participants were invited to explore tools that support and supplant theories and models and to visit examples of professional PLN venues/platforms. A remarkable environment suggested to the attendees should be mentioned: Tapped In (Fig. 3). It is a special type of PLN where users enjoy their PLE. It is a space for meeting and work online for an international community of professionals of education: K-12 teachers and librarians, engaged in projects for professional development and training for teachers, students, researchers and teachers.

\section{Tapped In Campus Map}

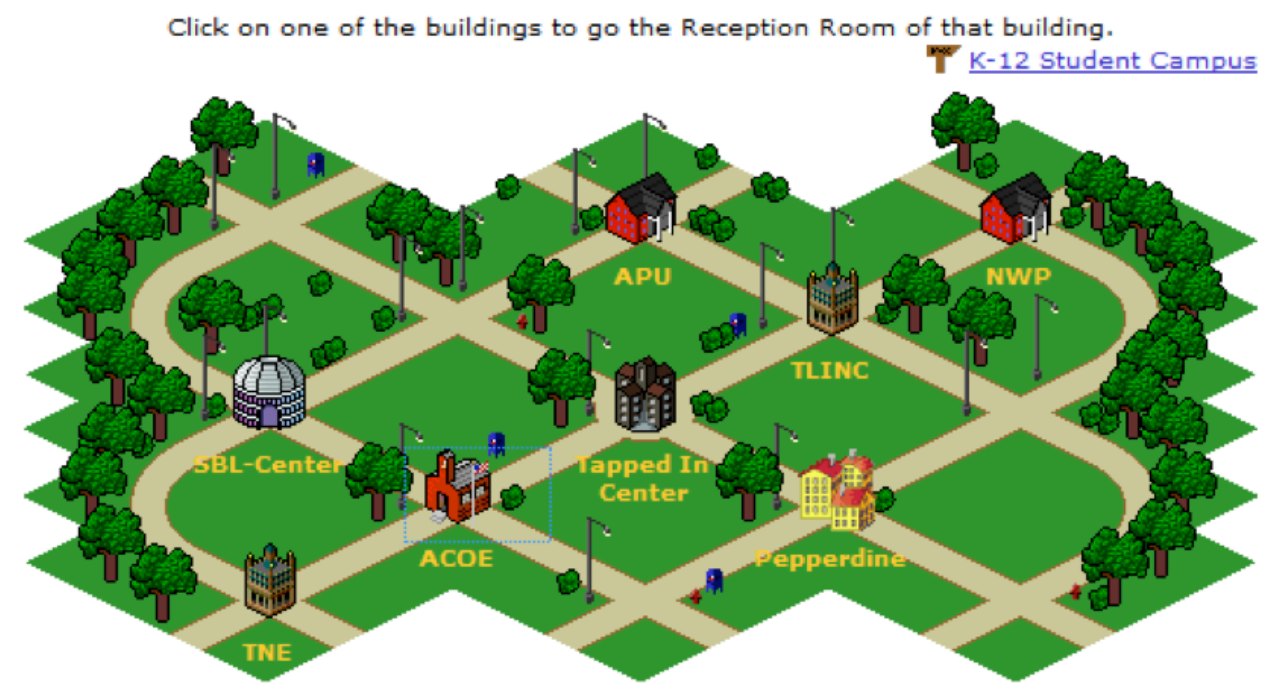

Fig. 4. Tapped In

Here follow the key features of Tapped in:

- Interactions occur mostly in chat, on a discussion board, according to a schedule previously set on topics of common interest and discussion for communities of practice is widened and open to guests. The chat transcript is automatically sent by e-mail to all participants;

- There is then a space for notes, a sort of 'wall', a tool that is spreading in different contexts, where people leave notes, ideas and memos;

- There is also a whiteboard used for brainstorming activities and/or sharing ideas when chatting;

- A welcome hall, a sort of reception where there is always a helper for orientation;

- A library with all kinds of useful resources;

- A section 'passageways' in which everyone can record the chat rooms he/she prefers;

- A widget to see online users;

- A repository of files and resources;

- A bookmarking space;

- A personal profile section;

- A 'personal office', with a private chat room. 
Week 4

During this week, participants were invited to post their PLE/PLN on the participants' project chart. They were invited to visit each other's PLE/PLNs, provide feedback and to take a survey on their favourite tools and purposes.

Participants shared their own PLE/PLNs, they analyzed some open source software, visited each other's and took a survey on their favourite tools/frameworks and purposes. Emphasis was on creating, sharing, discussion and feedback.

\section{Week 5}

During this week participants were invited to present their work; share the results of the survey on favourite tools with the group; evaluate the session in a final survey; present the work and wrap-up. During this final week we presented the general outcomes of the session and shared the results of the survey on favourite tools with the group, so everyone could benefit from a reference list created by the entire class. The added value of the class community was highlighted by the enthusiasm, passion and creativity the attendees showed during the session. The sense of community made it easier to re-mediate and innovate the traditional processes of knowledge management and delivery. The picture below shows the main tools and instruments adopted and experimented during the session.

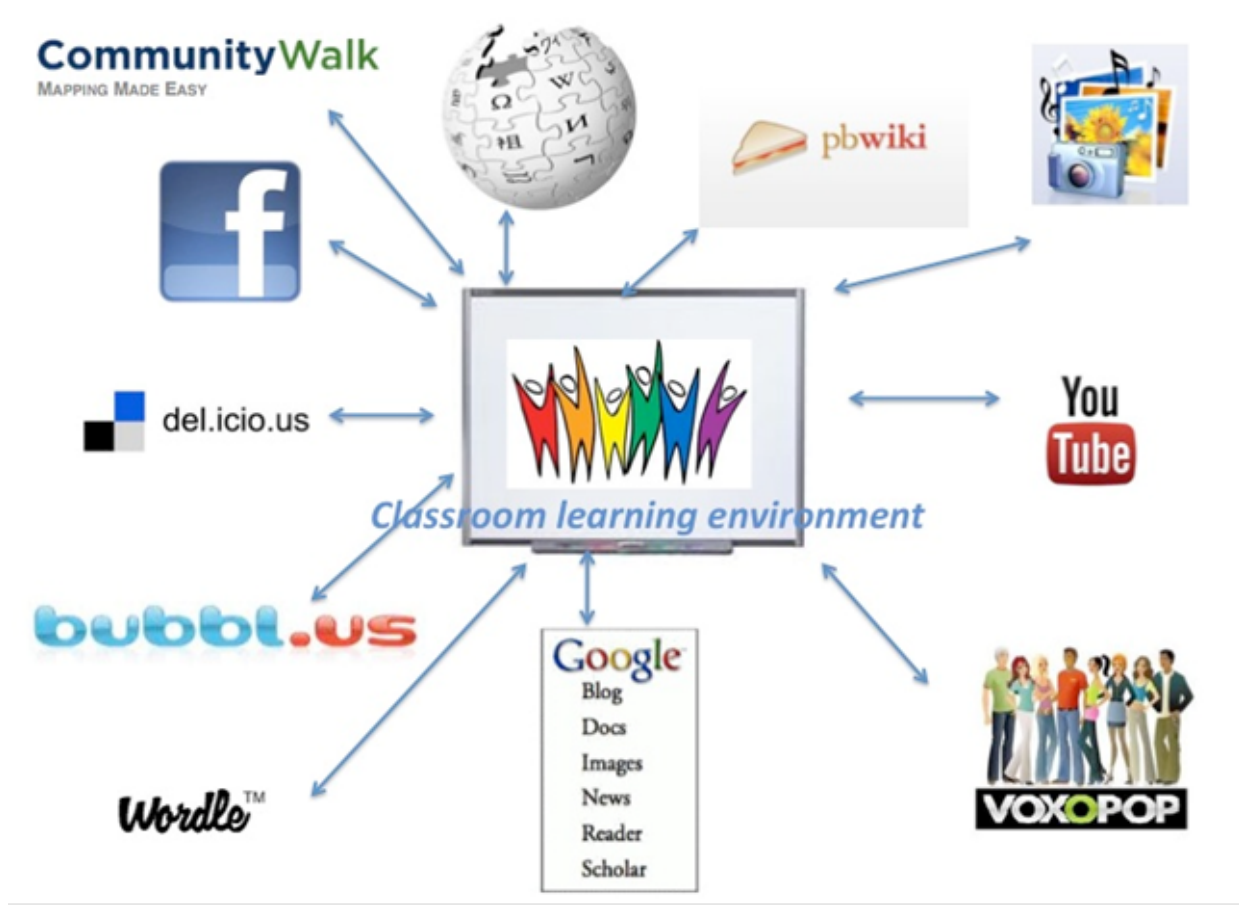

Fig. 5. The Session Learning Environment

\section{Webinars}

Weekly webinars turned out to be particularly effective, as they offered participants the opportunity to get hints and suggestions from expert speakers and at the same time interact with each other, asking questions, posing doubts, requests for clarifications, etc. The picture below shows an example of a webinar run by Graham Stanley ${ }^{13}$ from the British Council and Marisa Constantinides ${ }^{14}$ from CELT Athens,

\footnotetext{
${ }^{13} \mathrm{http}: / /$ blog-efl.blogspot.it
} 
describing the above-mentioned "aPLaNet" project (see paragraph 2.2.). Participants were happy to listen to the presentation, watch the slides shared in the virtual class through WizIQ15 and were eager to write in the chat box to express their feelings (as shown by the emoticons in Fig. 6), their curiosity and their desire for understanding and learning.

We found that webinars are a good way to deliver content and presentation and participants can be really interactive and actively involved in the process by responding to polls, posting emoticons (smileys but also clapping hands, thumbs up/down etc.), writing in the chat box, raising hands to speak, inviting the moderators or other participants to private chats etc. So we can say we really experimented the webinar as an effective communication and learning tool.

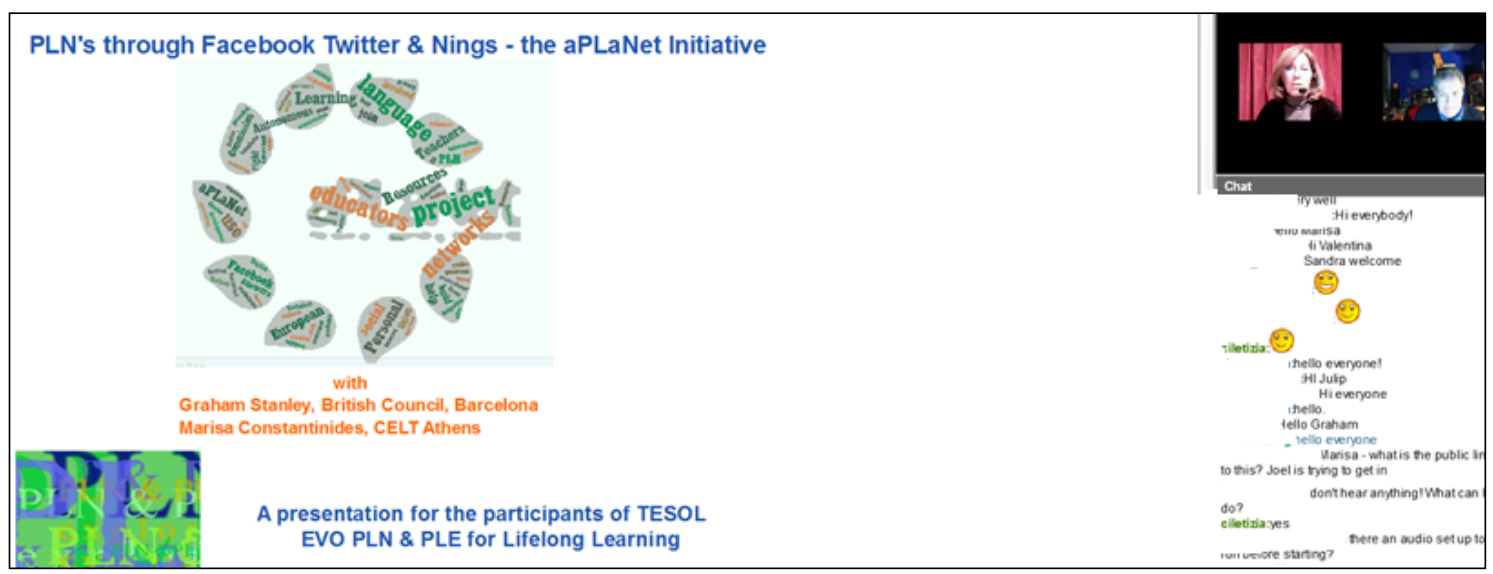

Fig. 6. Marisa Constantinides and Graham Stanley's webinar

\section{The Moodle and the wiki}

The Moodle platform ${ }^{16}$ was the main environment used for the asynchronous activities. Participants could post their ideas, material, experience in the forum and comment on their peers' posts. We fostered this practice a great deal as reflecting on a colleague's work can get to a better awareness of teaching practices and to a full metacognition. One of the most interesting tasks participants were invited to carry out was posting and sharing their own choices for creating a PLE\&PLN. As an example, we mention here a blog created by an attendee ${ }^{17}$, who decided to use it as a personal diary, a sort of e-portfolio to keep track and record all her activities in EVO. It is still active and the teacher has continued attending the following EVO sessions and is still using the blog as her personal learning diary.

\footnotetext{
${ }^{14} \mathrm{http}: / /$ www.celt.edu.gr/Marisa_Constantinides.htm

${ }^{15} \mathrm{https}: / /$ www.wiziq.com/home/

${ }^{16} \mathrm{http}: / /$ webteachertools.com/wtt/course/view.php?id=872

${ }^{17}$ Maria Rita Pepe: http://mrp4evo.blogspot.it/
} 
Sunday, February 12, 2012

\title{
The beginning of a PLE?
}

\author{
EVO 2012 - PLE \& PLN for Lifelong Learning
}

EVO 2012 has come to an end. But I have decided that this will be only the first of my EVO sessions. This blog has worked as my e-portfolio so far and it vill become (or already is?) part of my PLE.

As I could not take part in the PLE \& PLN for Lifelong Learning course final webinar, I decided to embed here the final presentation that Letizia, one of our moderators, kindly shared with us. It vill help me to vrap up this amazing learning experience and I will thus be able to share it with other colleagues who could not join the session.

Thanks to Letizia, Daniela, Susan and Sandra. You've been great moderators ad mentors.

\section{EVO PLECPLN Webinar}

\section{PLE and PNE for Lifelong Learning}

The Electronic Village Online (EVO)

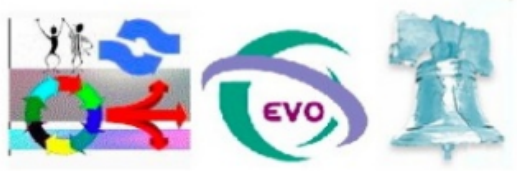

A Project of TESOL's CALL Interest Section 2012 Sessions

\section{Sandra Rogers}

Daniela Cuccurullo - Susan Burg - Letizia Cinganotto

Fig. 7. An example of a participant's PLE \& PLN

The wiki ${ }^{18}$ was another very useful working tool, especially for the cooperative dimension it helps to develop. Participants were invited to share their favourite tools, their ideas about PLE \& PLN, the definitions of the most common technological terms, their final products. The result is a rich repository of links, tools, definitions and resources, which can offer hints for inspiration to the wider community of teachers, trainers and educators.

18http://personallearningnetworksession.pbworks.com/w/page/33391448/FrontPage 
Online Technology Glossary

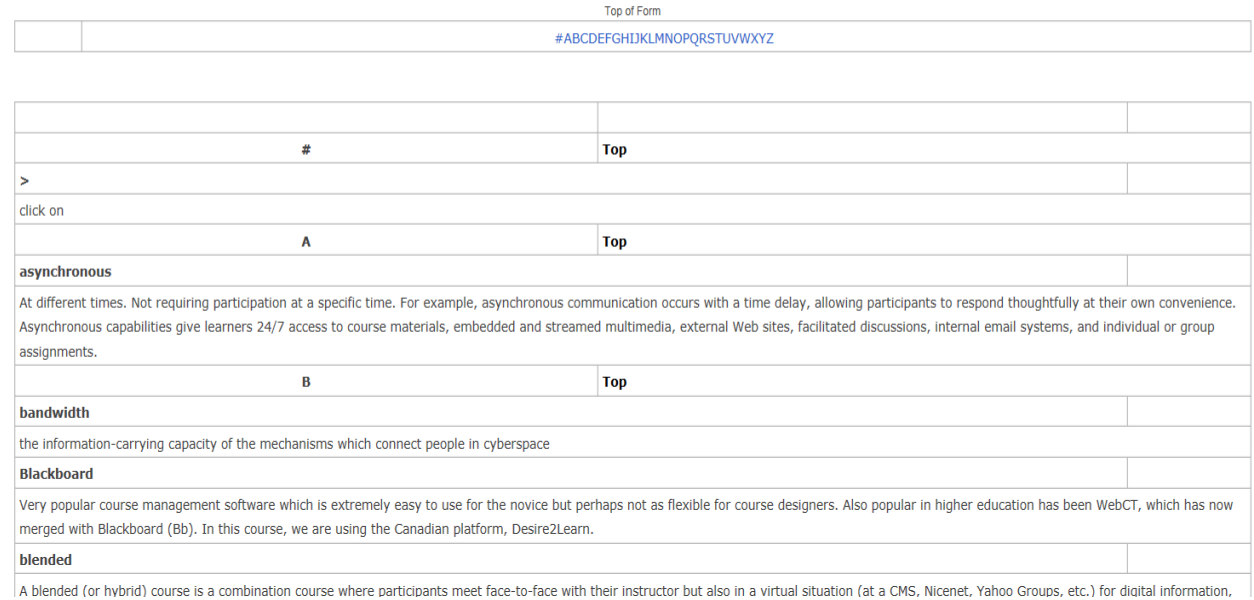

Fig. 8. The collaborative glossary on the wiki

\section{Outcomes and feedback}

As a general outcome we found out that the two concepts - PLE and PLN - were mainly related more to the process than to the product. Few managed to 'fix' in a framework their learning space, which by its own nature is constantly changing, both personally and socially. There was a great interest in the subject, there were attempts of definition and implementation, but, as in most experts 'environments', the resolution is still in progress.

The feedback from the participants was rewarding as they were all grateful for helping them discover a new world and a new way to design their learning experiences and maybe their whole life, considering not only the professional dimension, but also the personal one.

The examples of blogs, wikis and other social spaces designed by the participants for learning and interacting are attempts to create their own PLE and PLN after learning more about the underlying theoretical framework. We may say these attempts represent for us the best outcomes, the most suitable way to show the participants' understanding of the concepts proposed and their will to switch from theory to practice, as meant at the beginning of the session. It is encouraging to think that we provided the participants with materials, hints and suggestions, eliciting their hunger for learning and for changing their learning and teaching habits.

\section{Conclusions}

The aim of this project was to analyze the characteristics and potentialities of Personal Learning Environments/Networks and to provide the participants the opportunity for a complex personalized learning experience. The basic idea of the PLE is to combine formal and informal learning through the legitimacy of using open resources on the net. In this perspective, the complex learning experience taking place in personal learning environments - if promoted in institutional environments - does not represent a rupture or an alternative to the instances of formal education: these can be incorporated within a PLE/PNE by integrating with traditional e-learning platforms. Teachers, educators and individuals seeking an innovative answer to the "lifelong competency" management approach and looking for challenges as 
regards understanding, exploring and supporting new learning dimensions may get possible hints and suggestions from the implementation of a PLE and PLN as shown in the case study above. The integration of technology in language learning can represent a very powerful added value to the school curricula. The contribution was aimed at describing the outcomes of this initiative which were collected in a "multi-tool environment" for the production of digital content and the processing of knowledge outside the formal directions designed by school curricula and by institutional training pathways.

\section{References}

Atkinsin, D. (2011). Alternative Approaches to Second Language Acquisition. Routledge.

Attwell, G. (2007). Personal Learning Environments-the future of eLearning? eLearning papers, 2(1), 1-7.

Buchem I., Attwell G., Torres R. (2011). Understanding Personal Learning Environments: Literature review and synthesis through the Activity Theory lens. pp. 1-33, Proceedings of The PLE Conference 2011, 10th - 12th July 2011. Southampton, UK.

Chatti, M. A., Agustiawan, M. R., Jarke, M., \& Specht, M. (2010). Toward a Personal Learning Environment Framework. International Journal of Virtual and Personal Learning Environments, 1(4), 66-85.

Couros, A. (2010). Developing Personal Learning Networks for Open \& Social Learning. In Veletsianos, G. (Ed). Emerging Technologies in Distance Education. Edmonton: Athabasca University Press.

Downes, S. (2010). New Technology Supporting Informal Learning. Journal of Emerging Technologies in Web Intelligence, 2(1), 27-33.

Drexler, W. (2010). The networked student model for construction of personal learning environments: Balancing teacher control and student autonomy. Australasian Journal of Educational Technology, 26(3), 369-385.

European Commission (2014). Improving the effectiveness of language learning: CLIL and computer assisted language learning, June, 2014. Retrieved from: http://ec.europa.eu/languages/library/studies/clil-call_en.pdf

Farr, F., \& Murray L. (2016). The Routledge Handbook of Language Learning and Technology. Routledge.

Haste, H. (2009). What is 'competence' and how should education incorporate new technology's tools to generate 'competent civic agents'. Curriculum Journal, 20(3), 207-223.

Milligan, C., Johnson, M., Sharples, P., Wilson, S., \& Liber, O. (2006). Developing a reference model to describe the personal learning environment. In W. Nejdl \& K. Tochtermann (Eds.), Innovative Approaches for Learning and Knowledge Sharing - First European Conference on Technology Enhanced Learning, ECTEL 2006 (pp. 506-511). Berlin/Heidelberg: Springer.

OECD, (1996). Lifelong Learning for All.

Olivier, B. and Liber, O. (2001). Lifelong Learning: the need for portable Personal Learning Environments and supporting interoperability standards. JISC Center for Educational Technology, Interoperability Standards, Bolton Institute.

Scardamalia, M., \& Bereiter, C. (2006). Knowledge Building: theory, pedagogy and technology. In Sawyer K. (ed.), Cambridge Handbook of the learning sciences (pp. 97-118), New York: Cambridge University Press.

Shaikh Z.A., Khoja S. A. (2012). Role of Teacher in Personal Learning Environments. Digital Education Review - Number 21, June - http://greav.ub.edu/der/

Stanley G., Thornbury S. (2013). Language Learning with technology. Cambridge University Press. 
Letizia Cinganotto \& Daniela Cuccurullo

Walker A., White G. (2013). Technology Enhanced Language Learning. Oxford University Press.

Wild, F., Mödritscher, F. \& Sigurdarson, S. (2008). Designing for Change: Mash-Up Personal Learning Environments, eLearning Papers, 9/July.

Received: 28/02/2016

Accepted: 12/12/2016 